\title{
Effect of Vibrio alginolyticus on larval survival of the blue mussel Mytilus galloprovincialis
}

\author{
Casandra Anguiano-Beltrán ${ }^{1, *}$, Marcial Leonardo Lizárraga-Partida², \\ Ricardo Searcy-Bernal ${ }^{1}$ \\ ${ }^{1}$ Instituto de Investigaciones Oceanológicas, Universidad Autónoma de Baja California, Apartado Postal 453, \\ Ensenada BC 22800, Mexico \\ ${ }^{2}$ Centro de Investigación Científica y de Educación Superior de Ensenada (CICESE), Km 107 carret, Tijuana-Ensenada, \\ Ensenada BC 22860, Mexico
}

\begin{abstract}
The effect of increasing concentrations of Vibrio alginolyticus on survival of Mytilus galloprovincialis larvae was studied in a $48 \mathrm{~h}$ static bioassay in 11 glass bottles. Five bacterial densities were tested ranging from $10^{2}$ to $10^{6}$ bacteria $\mathrm{ml}^{-1}$. Larval survival and normality (veliger larvae with the typical D-shape) were evaluated after $48 \mathrm{~h}$. An inverse relationship between bacterial concentration and larval survival and normality was observed. In spite of high larval survival $(79 \%)$ under conditions of high bacterial density $\left(10^{5}\right.$ bacteria $\left.\mathrm{ml}^{-1}\right)$, the percent of normal larvae was $11 \%$. Besides an irregular shape, abnormal larvae also presented velum reduction. Results from this study suggest that concentrations of $V$. alginolyticus lower than $10^{3}$ bacteria $\mathrm{ml}^{-1}$ should be maintained during M. galloprovincialis larval culture.
\end{abstract}

KEY WORDS: Mussels $\cdot$ Mytilus $\cdot$ Pathogenicity $\cdot$ Vibriosis $\cdot$ Mollusks $\cdot$ Vibrio alginolyticus

\section{INTRODUCTION}

Blue mussel farming has become an important activity in Ensenada, Baja California, Mexico. Mussel production increased from 205 to 343 metric tons during the period 1996 to 2001 (H. Valles, SAGARPA, Ensanada BC, Mexico, pers. comm.). Since 1989, blue mussel spat have been produced in aquacultural laboratories of Ensenada, where epizootic events have occurred during the larval stage (García-Pámanes 1990); however, no attempts have been made to identify the cause of such mortalities.

Studies in Mexican invertebrate hatcheries have documented Vibrio-like bacteria (VLB) at concentrations between $10^{2}$ and $10^{3}$ bacteria $\mathrm{ml}^{-1}$ (LizárragaPartida et al. 1998, López-Torres \& Lizárraga-Partida 2001, López-Torres et al. 2001). Similar concentrations have been reported in samples from highly sewagepolluted areas (Lizárraga-Partida \& Vargas-Cárdenas 1996, Portillo-López \& Lizárraga-Partida 1997). However, it has been observed in aquaculture facilities that high concentrations of VLB do not always result in significant larval mortality (Lizárraga-Partida et al. 1997, López-Torres \& Lizárraga-Partida 2001, LópezTorres et al. 2001).

Different species of Vibrio have been identified as major pathogens in bivalve larval cultures, especially oysters and clams (Guillard 1959, Brown 1983, Douillet \& Langdon 1993, Riquelme et al. 1995, Sainz et al. 1998, Sugumar et al. 1998). The most common problem reported is bacillary necrosis (Tubiash et al. 1965, Lodeiros et al. 1987); however, the inhibition of filtration (McHenery \& Birkbeck 1986, Birkbeck et al. 1987) and the loss of swimming ability have also been observed (Nottage \& Birkbeck 1987, Nottage et al. 1989). Vibrio alginolyticus has been reported as one of the most pathogenic bacteria for molluscan larvae (Tubiash \& Otto 1986, Anguiano-Beltrán et al. 1998, Luna-González et al. 2002). This study investigated the effects of increasing concentrations of $V$. alginolyticus ATCC 17749 on survival and normality of blue mussel Mytilus galloprovincialis larvae. 


\section{MATERIALS AND METHODS}

A completely randomized experimental design was followed to evaluate the effects of bacteria on Mytilus galloprovincialis larvae. Mussel eggs were obtained by spawning ripe adults according to standard procedures (Loosanoff \& Davis 1963). To remove bacterial flora, fertilized eggs were washed with $0.45 \mu \mathrm{m}$-filtered, autoclaved seawater and placed in $1 \mathrm{l}$ experimental units (EUs) filled with $600 \mathrm{ml}$ of $0.45 \mu \mathrm{m}$ filtered and autoclaved seawater at a density of $67 \pm 6.8$ eggs ml${ }^{-1}$ and maintained at constant temperature $\left(20 \pm 1^{\circ} \mathrm{C}\right)$. Air was bubbled into each EU after passing through Gelman (bacterial air vent) $0.45 \mu \mathrm{m}$-filters. Previous experiments to test the sterility of the EUs indicated that after $72 \mathrm{~h}$ of bubbling air into peptone broth, no bacteria were introduced by the air system. After the introduction of fertilized eggs into each EU, a $0.1 \mathrm{ml}$ water sample was seeded into TCBS agar to evaluate the possible introduction of VLB.

A reference strain (Gherna \& Pienta 1992) of Vibrio alginolyticus (ATCC 17749) was cultured on Zobell agar media (Difco 1984) and incubated at $26 \pm 1^{\circ} \mathrm{C}$ for $24 \mathrm{~h}$. Bacteria were harvested, diluted and inoculated into EUs to obtain 5 treatment concentrations $\left(10^{2}, 10^{3}\right.$, $10^{4}, 10^{5}$ and $10^{6}$ bacteria $\mathrm{ml}^{-1}$ ). Cell concentrations were derived from a previously obtained equation

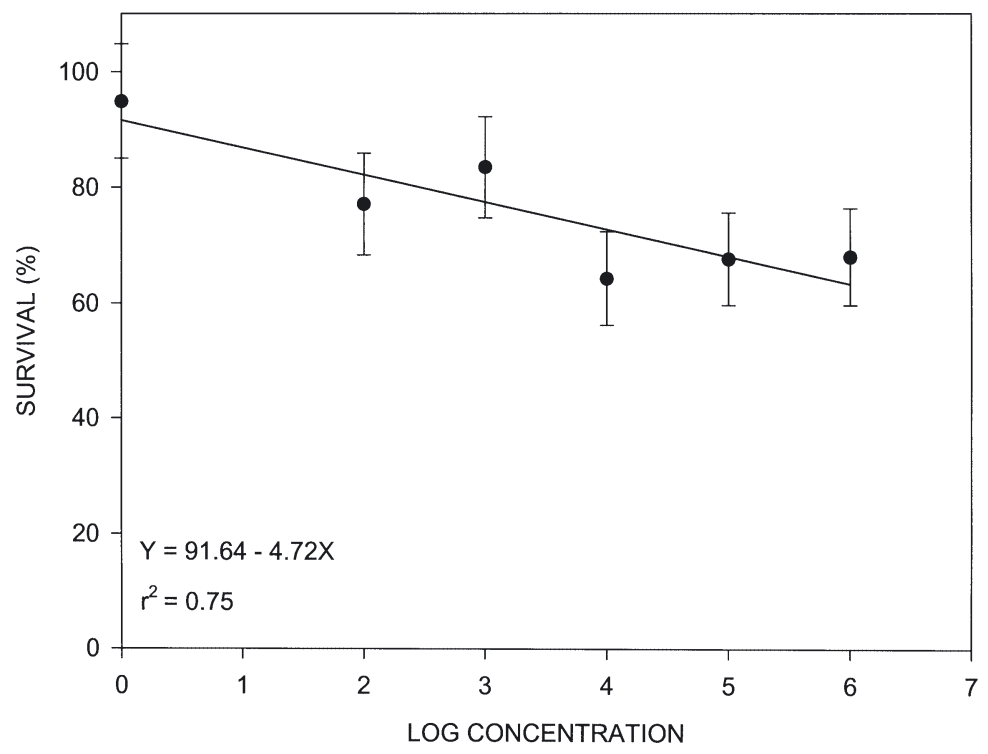

Fig. 1. Mytilus galloprovincialis. Survival of larvae in different Vibrio alginolyticus concentrations after $48 \mathrm{~h}$. Solid line is the fitted regression, vertical bars are SEs $(n=5)$ relating spectrophotometric absorbance $(600 \mathrm{~nm})$ and bacterial concentration after staining with DAPI (Porter \& Feig 1980, Anguiano-Beltrán 1996). As a control condition, EUs without bacterial inoculums were used. Actual inoculum concentrations were evaluated on TCBS agar after inoculation of $V$. alginolyticus into EUs. Five replicates of each bacterial treatment were used.

Samples of larvae $(1 \mathrm{ml})$ were taken from each EU at the beginning of the experiment and after $48 \mathrm{~h}$. Samples were examined under a light microscope using a Sedgwick-Rafter chamber. Survival of larvae was calculated as the number of veliger larvae developed from the initial number of fertilized eggs. This number included normal and abnormal veliger larvae. Normal larvae were considered as those that developed the standard ' $\mathrm{D}$ '-shape shell and a typical velum, while abnormal larvae did not develop this feature and presented a reduced velum. One-way ANOVA on transformed data (arcsine $\sqrt{ } \mathrm{p}$ ) and linear regression analyses were used to test the effect of treatments on the percentage of larvae survival and normality (Sokal \& Rohlf 1995).

\section{RESULTS}

Negative results of VLB were detected in all samples collected after the introduction of fertilized eggs into the EUs, suggesting that VLBs were not present on the mussel eggs. The actual initial concentrations of Vibrio algynolyticus for each treatment were $3 \times 10^{2}, 2 \times 10^{3}, 3 \times 10^{4}, 4 \times 10^{5}$ and $3 \times$ $10^{6}$ bacteria $\mathrm{ml}^{-1}$.

Larval survival (Fig. 1) was between 64 and $95 \%$ for the different bacterial concentrations. Minimum survival $(64 \%)$ was found in $3 \times 10^{4}$ bacteria $\mathrm{ml}^{-1}$, and the maximum in the control treatment $(95 \%)$. ANOVA of mussel larvae survival indicated that significant differences were found among treatments $(p<0.001$, Table 1$)$, and linear regression of survival versus bacterial concentration was significant $(\mathrm{p}<0.05)$.

Larval normality showed highly significant differences among treatments $(p<0.001$; Table 2$)$. In the 
Table 2. One-way ANOVA for normal percent of Mytilus galloprovincialis larvae cultured in different Vibrio alginolyticus concentrations

\begin{tabular}{|lcrcrc|}
\hline Source & SS & df & MS & $F$ & p \\
\hline Between concentrations & 3.967642 & 5 & 0.793528 & 98.97 & $3.26 \times 10^{-15}$ \\
Within concentrations & 0.192414 & 24 & 0.008017 & & \\
Total & 4.160056 & 29 & & & \\
\hline
\end{tabular}

Table 3 summarizes previous reports regarding the effects of Vibrio spp. on several mollusk larvae. Pathogenic effects of the same bacteria may not be similar for different species of larvae. In this study, a $32 \%$ mortality of Mytilus galloprovincialis larvae was observed in $3 \times$ $10^{6}$ bacteria $\mathrm{ml}^{-1}$ of $V$. alginolyticus whereas in a previous study, AnguianoBeltrán et al. (1998) reported mortalities

control, a mean percentage of $91 \%$ normal larvae was found versus $12 \%$ in $3 \times 10^{6}$ bacteria $\mathrm{ml}^{-1}$ of Vibrio algnolyticus (Fig. 2). Normality decreased as the bacterial concentration increased, and linear regression of larval normality versus bacterial concentration was significant $(\mathrm{p}<0.01)$.

\section{DISCUSSION}

Large differences were observed among the percentages of larval normality in increasing concentrations of Vibrio alginolyticus, but larval survival did not show such dramatic differences. The difference between maximum (95\%) and minimum (64\%) survival was only $31 \%$ (Fig. 1).

In contrast, evaluation of larval normality clearly shows sub-lethal effects of the bacteria on veliger mussel larvae. In the control treatment (Fig. 2) 91\% of the larvae developed the standard D-shaped shell, but at $3 \times 10^{2}$ bacteria $\mathrm{ml}^{-1}$, this number decreased to $57 \%$. A critical concentration threshold seems to be located between $2 \times 10^{3}$ and $3 \times 10^{4}$ bacteria $\mathrm{ml}^{-1}$, where normal $\mathrm{D}$-veliger larvae change from a mean percentage of 50 to $20 \%$. These results are in agreement with Brown \& Losee (1978), who reported that an inoculum of $1.6 \times 10^{3}$ bacteria $\mathrm{ml}^{-1}$ of Vibrio anguillarum in Crassostrea virginica larvae cultures (fertilized eggs to D-veliger phase) resulted in $22 \%$ survival, whereas $2.4 \times 10^{4}$ bacteria $\mathrm{ml}^{-1}$ resulted in only $2.4 \%$ survival. These authors suggested that some type of toxic substance could act as a teratogen, promoting abnormal development of fertilized oyster eggs, and also mentioned that Vibrio concentrations of $1 \times$ $10^{6}$ bacteria $\mathrm{ml}^{-1}$ allowed the potentially teratogenic metabolite to accumulate to its effective level before the fertilized eggs reached the straight-hinge stage; however, the results in this work show that a concentration of $3 \times 10^{4}$ decreased the normal development of Mytilus galloprovinciallis larvae drastically (by $80 \%$ ). of $100 \%$ in $1 \times 10^{6}$ bacteria $\mathrm{ml}^{-1}$ with Haliotis rufescens larvae and post-larvae after a period of $24 \mathrm{~h}$ of exposure to the same bacterial species. Luna-González et al. (2002) reported that Argopecten ventricosus, Atrina maura and Nodipecten subnudosus were more susceptible to $V$. alginolyticus than was Crassostrea gigas (Table 3). Also Nicolas et al. (1996) reported that a Vibrio strain related to $V$. splendidus was virulent to Pecten maximus larvae, but was not pathogenic for oyster larvae. However, Sugumar et al. (1998) found that some isolates of $V$. splendidus were pathogenic for oyster larvae (C. gigas) at $10^{5}$ bacteria $\mathrm{ml}^{-1}$, producing $100 \%$ of mortality in $24 \mathrm{~h}$.

Likewise, differences in susceptibility of the same molluscan larvae to different bacterial species are also reported. Elston \& Leibovitz (1980) found that Crassostrea virginica larvae were more resistent to Vibrio sp. Isolate 981 (50\% of mortality in $10^{6}$ bacteria $\mathrm{ml}^{-1}$ ) than to Vibrio sp. Isolate 1031 (50\% of mortality in $5 \times$ $10^{3}$ bacteria $\mathrm{ml}^{-1}$ ) in a period of 6 and $5 \mathrm{~d}$, respectively, whereas Brown (1981) reported that Vibrio anguillarum Strains S1 and S2 produced high mortal-

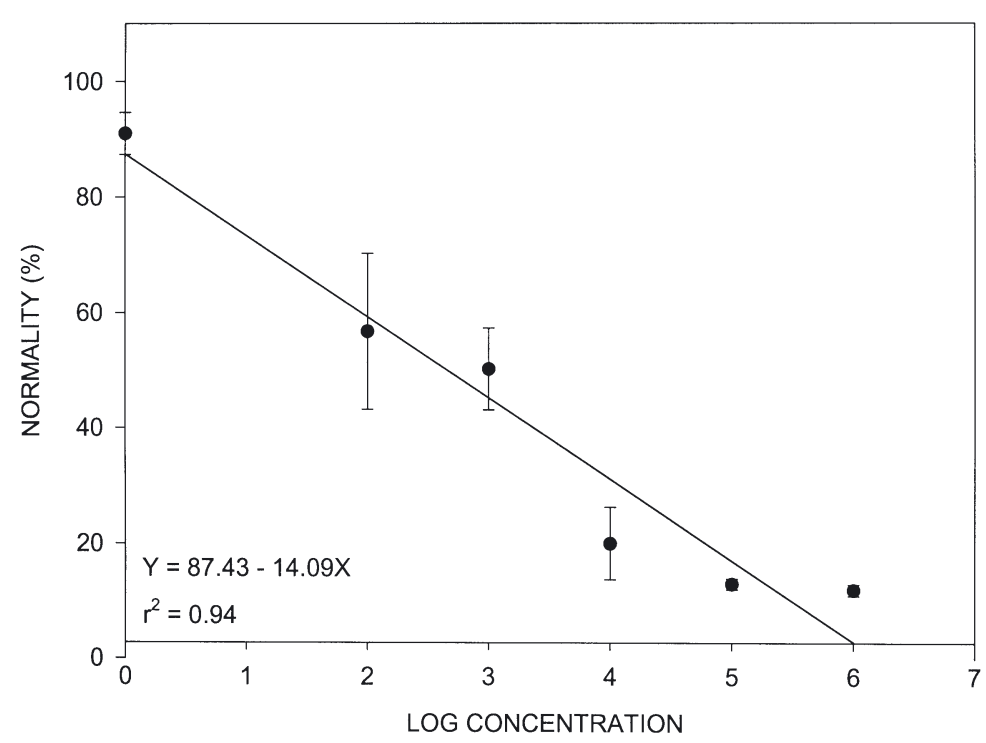

Fig. 2. Mytilus galloprovincialis. Normality of larvae in different Vibrio alginolyticus concentrations after $48 \mathrm{~h}$. Solid line is the fitted regression, vertical bars are SEs $(n=5)$ 
Table 3. Susceptibility of several molluscan larvae to different Vibrio species

\begin{tabular}{|c|c|c|c|c|c|}
\hline Mollusk & Bacteria & $\begin{array}{l}\text { Concentration } \\
\text { (bacteria } \mathrm{ml}^{-1} \text { ) }\end{array}$ & $\begin{array}{c}\text { Mortality } \\
(\%)\end{array}$ & $\begin{array}{c}\text { Time of } \\
\text { exposure }(\mathrm{h})\end{array}$ & Source \\
\hline Crassostrea virginica & Vibrio spp. & $1.2 \times 10^{5}$ & 12.9 & 48 & Brown (1973) \\
\hline Crassostrea virginica & Vibrio spp. & $3.9 \times 10^{8}$ & 99.9 & 48 & Brown (1973) \\
\hline Crassostrea virginica & Vibrio anguillarum & $2.4 \times 10^{4}$ & 98 & 24 & Brown \& Losee (1978) \\
\hline Crassostrea virginica & Vibrio sp. Isolate 98 & $1 \times 10^{6}$ & 50 & 144 & Elston \& Leibovitz (1980) \\
\hline Crassostrea virginica & Vibrio sp. Isolate 1031 & $5 \times 10^{3}$ & 50 & 120 & Elston \& Leibovitz (1980) \\
\hline Crassostrea virginica & Vibrio anguillarum S1 & $3 \times 10^{5}$ & 100 & 24 & Brown (1981) \\
\hline Crassostrea virginica & Vibrio anguillarum $\mathrm{S} 2$ & $1 \times 10^{5}$ & 100 & 24 & Brown (1981) \\
\hline Crassostrea gigas & Vibrio spp. & $2.1 \times 10^{5}$ & $>90$ & 48 & Jeffries (1982) \\
\hline Ostrea edulis & Vibrio spp. & $2.2 \times 10^{6}$ & $>90$ & 24 & Jeffries (1982) \\
\hline Ostrea edulis & Vibrio tubiashii EX1 & $1.7 \times 10^{2}$ & 70 & 36 & Lodeiros et al. (1987) \\
\hline Argopecten ventricosus & Vibrio alginolyticus & $90 \times 10^{5}$ & 100 & 48 & Sainz et al. (1998) \\
\hline Crassostrea gigas & Vibrio splendidus & $1 \times 10^{5}$ & 100 & 24 & Sugumar et al. (1998) \\
\hline Haliotis rufescens (larvae) & Vibrio alginolyticus & $1 \times 10^{6}$ & 100 & 24 & Anguiano-Beltrán et al. (1998) \\
\hline Haliotis rufescens (postlarvae) & Vibrio alginolyticus & $1 \times 10^{6}$ & 100 & 24 & Anguiano-Beltrán et al. (1998) \\
\hline Atrina maura ${ }^{\mathrm{a}}$ & Vibrio alginolyticus & $5 \times 10^{5}$ & $>95$ & 120 & Luna-González et al. (2002) \\
\hline Atrina ventricosus ${ }^{\mathrm{a}}$ & Vibrio alginolyticus & $5 \times 10^{5}$ & $>95$ & 120 & Luna-González et al. (2002) \\
\hline Nodipecten subnudosus ${ }^{\mathrm{a}}$ & Vibrio alginolyticus & $5 \times 10^{5}$ & $>95$ & 120 & Luna-González et al. (2002) \\
\hline Crassostrea gigas a & Vibrio alginolyticus & $5 \times 10^{5}$ & 60 & 120 & Luna-González et al. (2002) \\
\hline Mytilus galloprovincialis & Vibrio alginolyticus & $3 \times 10^{6}$ & 32 & 24 & This study \\
\hline
\end{tabular}

ity $\left(100 \%\right.$ in $10^{5}$ bacteria $\left.\mathrm{ml}^{-1}\right)$ on C. virginica larvae in only $1 \mathrm{~d}$. These results indicate differences of pathogenic effects according to the bacterial pathogen and differences in susceptibility among mollusk species.

Our data show that Vibrio alginolyticus do not cause massive mortality of mussel larvae, but that normal development can be severely affected. Nevertheless, in commercial farming operations these abnormal larvae will be discharged or they will die in the next phase of development. Therefore as a practical consideration, maintenance of VLB concentrations lower than $10^{3}$ bacteria $\mathrm{ml}^{-1}$ would be recommended to avoid the abnormal development of mussel larvae.

Specific detection of pathogenic Vibrio by polymerase chain reaction (PCR), genetic probes or monoclonal antibodies would help in the development of control measures in bivalve larval culture before bacterial problems appear; however, commercial laboratories do not have trained personnel and routine monitoring of Vibrio is not practiced.

Acknowledgements. The authors thank the laboratory of aquaculture of the Universidad Autónoma de Baja California for the donation of mussel larvae. We are also grateful to G. Vargas Cardenas for her help in laboratory work and 3 anonymous reviewers for their critical comments on the manuscript. This research was partially funded by the Mexican government (CoNaCyT grants 225080-5-3708-B. This work was part of the MSc research of C.A.B. (CoNaCyT scholarship 52083).

\section{LITERATURE CITED}

Anguiano-Beltrán C (1996) Patogenicidad de Vibrio alginolitycus sobre larvas del mejillón europeo Mytilus galloprovincialis y larvas y poslarvas del abulón rojo Haliotis fulgens. MSC thesis, CICESE, Ensenada

Anguiano-Beltrán C, Searcy-Bernal R, Lizárraga-Partida ML (1998) Pathogenic effects of Vibrio alginolyticus on larvae and poslarvae of the red abalone Haliotis rufescens. Dis Aquat Org 33:119-122

Birkbeck TH, McHenery JG, Nottage AS (1987) Inhibition of filtration in bivalves by marine vibrios. Aquaculture 67(1-2):247-248

Brown C (1973) The effects of some selected bacteria on embryos and larvae of the American oyster, Crassostrea virginica. J Invertebr Pathol 21:215-223

Brown C (1981) A study of two shelfish pathogenic Vibrio strains isolated from Long Island during a recent outbreak of disease. J Shellfish Res 1(1):83:87

Brown C (1983) Bacterial diseases in bivalve larval cultures and their control. P 230-242. In: Berg CJ Jr (ed) Culture of marine invertebrates selected readings. Hutchinson Publishing Company, Stroudsburg

Brown C, Losee C (1978) Observations on natural and induced epizootics of vibriosis in Crassostrea virginica larvae. J Invertebr Pathol 31:41-47

Difco (1984) Dehydrated culture media and reagents for microbiology, 10th edn. Difco laboratories, Detroit

Douillet PA, Langdon CJ (1993) Effects of marine bacteria on the culture of axenic oyster Crassostrea gigas (Thunberg) larvae. Biol Bull 184:36-51

Elston R, Leibovitz L (1980) Pathogenesis of experimental vibriosis in larval american oysters, Crassostrea virginica. Can J Fish Aquat Sci 37:964-978

García-Pámanes LE (1990) El cultivo de mejillón en México y la problemática asociada a la actividad. Serie Científica UABCS, México 1:19-24 
Gherna R, Pienta P (eds) (1992) Catalogue of bacteria and bacteriofagues, 18th edn. ATCC, Rockville

Guillard RRL (1959) Further evidence of the destruction of bivalve larvae by bacteria. Biol Bull 117:258-266

Jeffries VE (1982) Three Vibrio strains pathogenic to larvae of Crassostrea gigas and Ostrea edulis. Aquaculture 29: 201-226

Lizárraga-Partida ML, Vargas-Cárdenas G (1996) Influence of water circulation on marine and faecal bacteria in a mussel-growing area. Mar Pollut Bull 32:196-201

Lizárraga-Partida ML Montoya-Rodriguez L, Gendrop-Funes V (1997) The use of bacterial count in two mexican shrimp hatcheries. Cienc Mar 23(1):129-140

Lizárraga-Partida ML, Anguiano-Beltrán C, Searcy-Bernal R, Vazquez-Moreno E (1998) Bacterial water quality in abalone farms of Baja California. J Shellfish Res 17(3): 689-692

Lodeiros C, Bolinches J, Dopazo CP, Toranzo AE (1987) Bacillary necrosis in hatcheries of Ostrea edulis in Spain. Aquaculture 65:15-29

Loosanoff VL, Davis HC (1963) Rearing of bivalve molluscs. In: FS Russell (ed) Adv Mar Biol 1:1-136

López-Torres MC, Lizárraga-Partida ML (2001) Bacteria isolated on TCBS media associated with hatched Artemia cysts of commercial brands. Aquaculture 194:11-20

López-Torres MC, Macías Montes de Oca P, LizárragaPartida ML (2001) Evaluación de la calidad bacteriológia de dispositivos para limpieza de agua utilizados en acuacultura. Biotecnia 3(2):59-63

Luna-González A, Maeda-Martínez AN, Sainz JC, AscencioValle F (2002) Comparative susceptibility of veliger larvae of four bivalve mollusks to a Vibrio alginolyticus strain. Dis Aquat Org 49:221-226

McHenery JG, Birkbeck TH (1986) Inhibition of filtration in Mytilus edulis L. by marine vibrios. J Fish Dis 9:257-261

Editorial responsibility: Albert Sparks,

Seattle, Washington, USA
Nicolas JL, Corre S Gauthier G, Robert R, Ansquer D (1996) Bacterial problems associated with scallop Pecten maximus larval culture. Dis Aquat Org 27:67-76

Nottage AS, Birkbeck TH (1987) The role of toxins in Vibrio infections of bivalve mollusc. Aquaculture 67:244-246

Nottage AS, Sinclair PD, Birkbeck TH (1989) The role of lowmolecular ciliostatic toxins in Vibriosis of bivalve mollusks. J Aquat Anim Health 1:180-186

Porter KG, Feig YS (1980) The use of DAPI for identifying and counting aquatic microflora. Limnol Oceanogr 25:943-948

Portillo-López A, Lizárraga-Partida ML (1997) Detection of Vibrio cholerae $\mathrm{O} 1$ in diferent habitats of Todos Santos Bay, Baja California. Cienc Mar 23(4):435-447

Riquelme C, Hayashida G, Toranzo AE, Vilches J, Chavez P (1995) Pathogenicity studies on a Vibrio anguillarum related (VAR) strain causing an epizootic in Argopecten purpuratus larvae cultured in Chile. Dis Aquat Org 22:135-141

Sainz JC, Maeda-Martinez AN, Ascencio F (1998) experimental vibriosis induction with Vibrio alginolyticus of larvae of the catarina scallop (Argopecten ventricosus $=$ circularis) (Serby II, 1842). Microb Ecol 35:188-192

Sokal RR, Rohlf FS (1995) Biometry: the principles and practice of statistics in biological research, 3rd edn. Freeman, New York

Sugumar G, Nakai T, Hirata H, Matsubara D, Muroga K (1998) Vibrio splendidus Biovar II as the causative agent of bacilary necrosis of Japanese oyster Crassostrea gigas larvae. Dis Aquat Org 33:111-118

Tubiash HS, Otto SV (1986) Bacterial problems in oysters. A review. In: Vivarès CP, Bonami JR, Jasper E (eds) Pathology in marine aquaculture. European Aquaculture Society, Spec Publ 8, p 233-242

Tubiash HS, Chanley PE, Leifson E (1965) Bacillary necrosis, a disease of larval and juvenile bivalve mollusks. J Bacteriol 90(1):1036-1044

Submitted: April 27, 2002; Accepted: January 24, 2004

Proofs received from author(s): April 24, 2004 